\title{
Religion and Politics in Nigerian Society: Problems and Prospects (a Philosophic Probe)
}

\author{
Ogugua PaulIkechukwu, OguguaIfunanya Clara \\ Department of Philosophy, Nnamdi Azikiwe University, Awka, Nigeria \\ Email: paiykeo@yahoo.co.uk, ifunanyaoguguap@yahoo.com
}

Received 24 October 2014; accepted 23 March 2015; published 26 March 2015

Copyright (C) 2015 by authors and Scientific Research Publishing Inc.

This work is licensed under the Creative Commons Attribution International License (CC BY). http://creativecommons.org/licenses/by/4.0/

\section{(c) (i) Open Access}

\begin{abstract}
The concepts religion and politics are problematic even at the level of conceptualization. This paper examines the two concepts in the Nigerian society and points out some of the areas of problem, and goes on to argue that peaceful co-existence of both concepts in the Nigerian society is not only possible but also realizable.
\end{abstract}

\section{Keywords}

\section{Religion, Politics, Society, Problems, Prospect}

\section{Introduction}

Religion springs problems even at the level of conceptualization. All shades of articulation that relate to worship of forces or spirits do not have the same characteristics; this occasioned use of family resemblance definition accommodates all unqualified as religion, which in "strictusensu" need not qualify. Religion is a reality, though it is enigmatic and an elusive subject; hence, it defies a universally acceptable definition. Perceptions of scholars about religion vary. Lucretius said (as cited in (Mukozi, 1988)) Tantum religio potuit suadere malorum (such where the lengths) of wickedness to which religion could persuade human nature to go.

In the same vein, Voltaire insisted "crush that monster, religion and set western man's spirit free for pursuing this glorious enterprise of raising his culture to Olympian heights." Durrant (1920). For these scholars and those of their ilk, religion is a barrier to human self-actualization. There is no doubt that religion can be seen in this light when it has been turned into an ideological tool or else, why did Karl Marx see it as the opium of the people. A palliative used by the leaders to hold the masses in check.

In the hand of a villain, religion can be a cog in the wheel of progress and massaging of the ego and dehuma- 
nization of the people, while in the hand of a "saint" it becomes an instrument for humanization. For Ejizu (1986), man's value system and attitudinal orientations are basically the functions of one's religious belief. According to Makozi (1988), man as an individual is subject to a God who has created him. For him, the content of religion shapes the individual's life in society, regulates his relationship with other human beings and is at the root of political order for the fact that it gives legitimacy to civil law and forms of sovereignty. We can hold at this point that religion can become a double-edged sword. In short, it can become a paradoxical instrument in the hand of a few or even the state.

Politics is derived from the Greek root "polis" meaning city state. Implicitly is the idea of governance in the word "polis". For Onyekpe (2003), "politics is about the control and exercise of power". Madu (2004) sees it as “an integral feature of man's social existence and interaction”. In the understanding of Ejizu (1988), it is a dynamic process whereby human and other human resources are managed, directed after due mobilization to ensure the enforcement of public policy and decision in the bid to regulate social order. Some scholars use the term politics in a congruous sense: the struggle for power and the actual exercise of authority and power. Broadly speaking, politics covers every phase and aspect of life in society, for it is essentially about governance.

Philosophy etymologically speaking is love of wisdom. Philosophy has the good, the beauty and the truth as it objects (Ogugua, 1994: p. 2004); we can say without fear of contradiction that philosophy is a search for the truth. Jesus Christ did say that he was the way, the truth, and the life, so one could add that philosophy was the way and life at least as a pointer such as must X-ray morality and values expressed by Christ Jesus. Is it not this truth that philosophy is concerned with that made Socrates posit and the famous philosophical dictum "man know thyself'? The scriptures made it too clear that the truth would set us free. Philosophy is a path to knowledge and wisdom. Bacon has been presented to have said that knowledge is power. Knowledge is a path or a step to wisdom. Only the one who knows himself and has himself under control is wise. To be wise is to know what one knows, and to know and appreciate that one does not know everything and to make efforts in the bid to know more about reality and life, and live this knowledge. Or else why did Plato tie knowledge to virtue? Madu (2004) states. Therefore, in a way, knowledge and its application within one's existential situations sets one free. In other words, knowledge is synonymous with the truth.

There is no doubt that possession of knowledge will assist one to identify the "why", the "how" and the "what" of things. But we beg to disagree with Madu that knowledge is synonymous with the truth and that applying it within one's existential situation sets one free. We ask how knowledge of money in the bank, knowledge of the strength of security in the bank and knowledge of the shift run in the bank make one's plot to break into the bank to "help" himself set the said person free? So at this juncture, we relate the "know yourself" injunction to the Nigerian society (state).

Our topic is geared towards political stability; hence, we expect with the aid of political philosophy to realize welfare of members of the Nigerian society and establish a macrocosmic harmony by putting in place good political activity which solicits social justice and peace. Madu asserts:

The goal of politics according to experts of political economy is the realization of common wealth in a state. Invariably, the chief actors in any political economy are men. In fact, the existence of the web of relationship among men for mutual intercourse presupposes equally the feature of estrangement and strife among men. In a way, therefore, politics must have to come in to direct or modify their relationship to promote the attainment of the expected goals (Madu, 2004).

In this paper, we attempt to point out the root causes of the problems bedeviling our nation, and the reason why religion has not helped in ushering in the much desired stability shows that there exists a fundamental link between religion and politics, charting a course for progress and stability with both religion and politics being still inseparable.

\section{Religion and Politics in Society: Problematics}

In the Nigerian society three types of religion are prominent: Christianity, Islam and African traditional religion. The first two are imported religions; and the last is home grown. Both Christianity and Islam are universalistic while African traditional religion is particularistic. Impliedly, African traditional religion has no body of teaching which is regarded as valid forever (at all times) as it has no universal mission, so proselytization does not exist, hence African traditional religion cannot be a divisive force. So, traditional religion does not cause havoc 
in our society, the problem exists between Islamic and Christian religion.

The problems are at various levels: conceptualization, world-view, beliefs and perception among others. At the level of conceptualization and articulation both religions Islam and Christianity differ, their philosophies are poles apart as their founders are both in the largeness of heart cum intelligence and articulation of concepts. Christianity is not a parallel concept to Islam; nor is Christianization a parallel concept to Islamization. Each is in a world of its own. While Christianization concerns itself with conversion of willing persons, Islamization concerns itself with conversion of persons both in the spheres of religion and politics with the use of force. At this level, it is clear that Islamic religion is not concerned with human acts as such for these are acts performed with the aid of knowledge, freedom, voluntariness and intention. Again, it is not concerned with the worth, value and dignity of man, moreso with human rights as enunciated in UNO, African charter and constitutional provisions of human rights.

When we talk of world-view, it at times looks unweighty and irrelevant. But careful analysis and interest will show that it is "philosophical" in the sense of being based on the cosmology of a people, which if fine tuned philosophically shows it as an aspect of metaphysics which is at root of reality. Henry Alpern informs us in The March of Philosophy of the statement of David Hume an archempiricist as cited by Onyewuenyi, thus:

Metaphysics by the very definition that it is the study of reality, of that which does not appear to our senses, of truth in the absolute sense, is the groundwork of any theory concerning all phases of human behaviour... It is the foundation on which one builds...; upon its truth or falsity depends what types of man you may develop into (Onyewuenyi, 1983).

For Iroegbu,

There is a background to every experience. Nothing springs from nowhere. All experiences, including religious ones, have a foundation and springboard, which one may call the mother that gives birth to the experiences. Equally experience itself is also a father of basic tenets, including the metaphysical convictions and religious credo of persons and peoples... (Iroegbu, 2003).

And for Ogugua,

To understand a people, one usually focuses on their culture. Culture is exclusively a human phenomenon, quite complex, uniting and dividing human groups, as different peoples perceive life and reality differently. Culture is the totalization of all, a peoples' beliefs, moreso, arts, customs, etc learned, shared and equally transmitted from generation to generation in short; it embodies the manipulation of forces in their environment for better.

He stressed:

Beyond culture is the worldview of a people or in a more precise manner, alongside culture is the worldview of a people (Ogugua, 2005).

It is bizarreto think meaningfully of world-view without cosmology and at times cosmologies. A litany of texts, spate of articles have been written on cosmology with which we are more concerned "hic et nunc". It is not necessary for us now to relate, revolve and gravitate around the definitions postulated and deposited by scholars such as Achebe, Ejizu, \& Wambutda (1986), Metuh (1987), Onuoha (1987), Ubesie (1989), and Madubuko (1994). The central thread of all those definitions is that cosmologies are religious. Madu asserts:

One can simply explain this since cosmology focuses its search-light on the question of meaning of the world, its origin in spaces as well as the question of the intricate web of relationships within the cosmologic ontological hierarchies. Such questions implicate the quest for transcendental reality, a quest which is inherently a religious one (Madu, 2004).

You can see that basically speaking how one perceives his world or the structure of his universe could be said to be his world-view. Little wonder, Achebe (1986) did see it as a lens through which reality is perceived. We need to stretch further this concept of world-view to suit a philosophic discourse. For Okafor it is: ... the concepts of the world; physical and metaphysical held by a people... They are the basic notions underlying their cultural, religious and social activities (Okafor, 1992).

In the very words of Nwalait, it refers to the complex of beings, habits, laws, customs and tradition of a 
people. It includes the overall picture they have about reality, the universe, life and existence... (Nwala, 1985).

It stands to reason that it provides us with the database for philosophizing, Kraft sees it as "central control box" for designing and governing a peoples' relationships (Kraft, 1979). For Onuoha (1987), world-views are based on faith, hence could be said to be based on assumptions, calling more or less for emotional response. Worldviews are hostile to and intolerant of each other, hence could spring crises of all sorts. World views generate a kind of strong sense of self assurance, providing techniques for manipulation of reality to suit their viewpoints even though no critical reflection has been made. Do you now see that world-views are exclusive to themselves? Each world-view builds a niche for itself and fights to maintain it and even over run other worldviews. Ogugua did not mince words when he emphasized that world-view is non-critical, dogmatic and mythical. He stressed:

We cannot exclude their interrogations to decipher whether life is worth living or not. Although world-view is a kind of philosophy, it is not as such scientific, and consistent as academic philosophy, for it is essentially traditional, that is pre-modern but not illogical, irrational, primitive, etc. (Ogugua, 2005).

The fact that traditional religion is not universalist; and a proselytizing type, did not make it immune from the expansive mood of the other religions. There were conflicts initially between Christianity and traditional religion (as depicted in Achebe's Things fall Apart); likewise between Islam and traditional religion. Many scholars are of the opinion that the discomfiture between traditional religion and foreign ones are cultural and social. Wambutda accepted this position but went on to a more basic factor which revolves around our discourse. He asserts:

That the cultural and sociological factors do not give a fundamental and ultimate explanation for this gap and discomfiture, though these may indeed be apparent causes. We propose that the more ultimate, more fundamental and pristine causes for this discomfiture-between African and Western Christianity and indeed between culture is to be found in the cosmology of such cultures and societies (Wambutda, 1986).

The discomfiture generated by the interplay of cultures, cosmologies, world-views and hybridization of these need not be wished away with the wave of the hand, these conflicts are real and most often devastating. The encounters between Christianity and Roman culture or empire, and Christianity and traditional religion or even between Hausa-Fulani culture and Islam attest to the truism that world-views have a way of beclouding peoples' rational appetite. Do you now see that cosmologies and world-views are great and torrential forces capable of plunging any society into anarchy as they manifest in emotional outburst? They are more or less of the heart and not of the mind save one bring in reason to bear at it, Ekwunife pointed out:

In Nigeria, the government and her citizens are yet to accept fully both in theory and practice the stark realities of pluralism of religious beliefs and practices. The waves of religious crises and violence in recent years seem to confirm this observation (Ekwunife, 1992).

Although religion and politics are natural to man, in concrete situations more especially in groups more so within particularistic societies, these two elements or features of life fall apart. This is irrespective of the fact as Ekwunife stressed that: Politics and religion seem to have been two important cultural variables which influence the tone of societies all over the world. Their influence dates back to antiquity (Ekwunife, 1992).

Politicization of religion is one of the blind eyes of the Nigerian nation. Aguwa (1993) pointed out: Religion quite easily succumbs to politicization and one of the reason is that religion inclines towards a dialogic relation with several other socio-cultural institutions. In "diebusellis" religion performed several functions such as definition of goals and values, social integration, legitimatization of moral and political authority among others. Our age with its level of sophistication thinks some of these functions are better performed by other institutions. Experience has shown that when and where religion anchors politics, or tries to give it a base and not necessarily "guide" it in a pluralistic society, allegiance splits along religious lines. This has happened in Nigeria, as attempts made by some government reigmes to islamise Nigeria show. Instead of religion functioning as a catalyst to man's ultimate problem, it spins intolerance of one to the other, one group to the other.

For Ekwunife:

There is intolerance when any group in a society deliberately and violently sets out to stamp out what the members subjectively consider to be error in religious thought and practice.

He continued: 
There is religious intolerance when members of the self-acclaimed true religion proclaim in practice that persons they consider to be in error, have no right to live, no right to legitimate political, social and economic amenities unless they renounce their error and be converted to the supposed true religious views and practices (Ekwunife, 1992).

You can see this has to do with rigid dogmatic acceptance of a metaphysical or in a strict sense cosmological perception of reality and an epistemological bias and prejudice. This defies the fact of knowledge being perspectival and the Igbo adage "Okirikirikaanaagbaukwuoseadiro ali yaenu"-(one plucks the pepper seed by moving or going around the pepper shrub and not by climbing it) and "anaroofuebeekirimmuo"- (the masquerade is watched from different positions). Why? To set a good and enriched view so as not to act like the six blind men of Hindustan who went to experience the elephant and for one the elephant is like a rope having felt its tail and another a fan having experienced its ears, etc. Your cosmological exclusivism, refusal to look through another lens, accept or understand contrary views is usually accompanied by series of series of violence and destruction, moreso, as some people want to go to heaven ill prepared, carelessly by simply causing mayhem and killing "infidels".

In politics too, Nigeria has been torn apart as we have experienced high level of ethnicism and regionalism skillfully and craftily orchestrated by the colonial and post-colonial administrations. Amucheazi stated: One of the legacies of colonial regime in Nigeria was reinforcement, to a degree of sub-national loyalties (Amucheazi, 1986). This is the reason (why) the focusing of identity never shifted to Nigeria, but remained with the region and/or the ethnic group. It is not surprising for Leon Dare to emphasize that "none of the parties in the real sense of the term, could be said to qualify as a national political organization" (Leon Dare, 1985).

He was referring to the first republic parties. But even in the third Republic political parties none still could be said to be national in outlook. Whatever national outlook any of them exudes is apparent. Aguwa asserts: The inability of these parties as well as subsequent ones to rise beyond regional and ethnic interests has been undoing of genuine exercise of democracy in Nigeria (Aguwa, 1992). There is no doubt that there are problems in the Nigerian polity with regards to religion and politics such as cosmological exclusivism, epistemological bias, myopia, leadership problem, misgovernance, lack of political culture, and the like. Now, let us see how we can solve these problems.

\section{Religion, Politics and Society: Any Connections?}

Culture is the widest of the matrices; it is wider than religion, and equally politics. The matrices of religion and politics fit in properly within the matrix of culture. And as society is identifiable by its culture likewise society is a wider matrix than any of these religion and politics. Before delving into the region of integrating both religion and politics to serve our society, we have first and foremost to concern ourselves with re-examining the concepts of politics and religion to see if they are related. If there is any iota, sign of relationship to see how deep it is. Is it accidental or basic (fundamental)?

Man is a political animal, but before developing into a political animal he was first and foremost a social or cultural animal that means he finds fulfillment in company of others of his kind. He is gregarious. But man's social life needs to be regulated and organized if he must relate properly with his fellows. The science of this complex set of relationships is the science of politics. Politics could then in a nut shell be said to be the science and art of governance; so it is the art of statecraft. By government we mean that social organization set up in every society with a view of some good purpose: enacting, codifying and enforcing both laws and moral (values) of any given society.

For Glenn, Government is unique among social institutions in that it typically has society's approval in using force to secure compliance with its norms (laws) (Glenn, 1962).

Aristotle had earlier asserted that:

Clearly then, as all associations aim at some good, that one which is supreme and which embraces all others will have also as its aim the supreme good. That is the association we call the state, and that type of association we call political (Aristotle, 1975).

So every government that worths its mettle and that knows its onions must be geared towards the common good of her citizens. In the light of proper understanding and perception one need then to agree with the Vatican 
II document (ed) by Flannery thus:

... The common good embraces the sum total of all those conditions of social life which enable individuals, families, and organizations to achieve complete and efficacious fulfillment... (Flannery, 1975).

Politics is both an art and a science; in short, a social science. For Russell "... the fundamental concept of social science is power, in the same sense in which Energy is the fundamental concept in physics" (Russell, 1971). Likewise one could hold that power is the central concept in politics; hence politics may be said to be a systematic ploy, move and attitudinal disposition or even act to have access to power; that means to have the ability to influence both actors and events or make things happen. Little wonder Russell defined power as:

... the production of intended effects. It is thus a quantitative concept: given two men with similar desires,

if one achieves all the desires that the other achieves and also others, he has more power than the other (Russell, 1971).

We may introduce the second arm of our tripod by asking; religion: what is it? Because of the simple fact that we have looked at this concept in the introduction of this work, we will look at it here to see if there are areas or level by which or through which we can link it to politics so as to hasten our move onward (towards) concluding this paper.

Alexander Skutch said:

We are religious because we love life and cling passionately to our conscious existence... Religion is life's ceaseless effort to preserve and perfect itself, become at least self-conscious, foreseeing and, in consequence, fearful amid the thousand perils that beset it. It was said of old, and has been reiterated by modern students of religion, that fear made the gods; but this is a half-truth. We fear only when that which we wish to preserve is threatened. Love of life, concern for the things that embellish it, is prior to fear.

When we pursue our analysis of it far enough, it becomes clear that it is our attachment to conscious existence, which made the gods.

Emphasizing he states:

Religion begins at its natural starting point, the instinct of self-preservation, which has been called the first law of nature. Its function has been to deepen and broaden this natural impulse (Skutch, 1970).

Many will pitch their tents with Alexander Sketch. It is not surprising that Harold Kushner did support his idea and asserts:

Religion begins with a sense of reverence, the recognition of God's greatness and our limitations. That is why there are no atheists in foxholes and few atheists in hospital... There are no atheists in foxholes because times like those bring us face to face with our limitations (Kushner, 1990).

We think of religion, moreso engage in it, because we are contingent beings, as we even lack the power to control vital things that matter most in our lives. In the words of Kushner, at the limits of our power, we use to turn to a power greater than ourselves. People have always found God at the limits of their own strength (Kushner, 1990).

Religion begins at the point where we are no longer too sure of ourselves, no longer in control, at the point we struggle in our conscious desire to succeed, in short, at the point of self preservation of course not in idleness, but in our engagement with life by performing some activities. It is within these activities that the connection between religion and politics could be located. Skutch observed:

For the present, it is enough to recognize three activities, or three attitudes, appropriate to our dealings with the three grades of being: art, for the exploitation of things that we deem inferior to ourselves; morality, for regulating our relations with things on the same plane as ourselves, and religion to place us in the proper relationships with whatever we regard as higher than ourselves (Skutch, 1990).

It is no longer difficult to see that politics is at the second level in Skutch's presentation and within the sphere of morality, the arena of human action/conduct. Do you now see that both politics and religion meet here? Since man is made in the image and likeness of God as expressed in Genesis 1:26, man is dependent on God and cannot be independent of God, for a master-servant relationship exists between them. Man relates to man within the 
sphere of religion. As man and society act on religion and politics both concepts are linked as a matter of cosmic necessity; for man must certainly relate to his fellows and to Supreme Being or higher forces or cosmic reality.

In Islam for instance there is no bifurcation between the religious sphere and the political sphere. Lateef observes that Islam:

Regulates not only matters of spiritual salvation and moral development but also economic and mundane affairs, as well as socio-political life, which other religions treat as temporal and therefore distinct from the spiritual (Lateef, 1974).

Christianity now based on the idea of secularity tends to separate politics from religion. But it was not like that originally, it only emerged in the middle ages (Pfeffer, 1987). According to Weber (1964), this same idea of political secularity reached Islamic world in the 12th century but it had very little or no acceptance. Even in Christendom, religion and politics have influenced each other. The establishment of the church's headquarters in Rome, was it not politically motivated? Akpunonu opined: It was a matter of pride and of good strategy to establish a foot hold in Rome. It served to get good information, to establish influence and to carry out financial transactions (Akpunonu, 1988).

It is a truism that political policies, principles and motives are generally built on religious precepts. Love of self and neighbour is a rendition of the golden rule, on which is anchored the Universal Declaration of Human Rights, which is at the fulcrum of democracy. Politics that is devoid of religious foundation or that is divorced from ethics is boneless, spineless and powerless. Or else why did Shagari stress "any nation, that places no value on moral standards is like a body without a soul" (Shagari, 1983).

Religion is no doubt an important variable in all facets of our life. Even our anthem emphasized this thus:

O God of creation, direct our noble cause, guide our leaders right, help our youths the truth to know, in love and honest to grow, and living just and true, great lofty heights attain to build a nation where peace and justice reign.

In both sphere of life, man finds himself engulfed. Politics is a human activity likewise religion, so we submit without mincing words that both concepts are fundamentally related, linked and intertwined like siamese twins, hence should be assigned respective and not conflicting roles in society.

\section{Towards Peaceful Co-Existence in a Religio-Political Crisis Situation}

Our topic is a historical, theological, religious, political and philosophical salad or hot potato capable of drawing a lot of attention and generating controversy. In the past few days there was great deal of religious ferment in the North which resulted in killing of many Igbo people who are known as Christians due to a press publication overseas which Muslims saw as a slight on Mohammed the founder of Islam. This killing in the North triggered reprisal killings in the South too.

As the Islamic religion does not accept the idea of bifurcation of the political and the religious sphere, it tilts towards theocracy. Islamic community is founded on faith as it is placed under the direct supervision of Allah. By implication, Islam sticks to orthodox tradition and as such sees the non-Moslems as "infidels" so has no grounds for interacting with them. In simple language, non-Moslems are seen as pariahs and treated as outcasts. Or else what made Sheikh Abubakar Mohammed Gumi, a Muslim leader and teacher to assert: Once you are a Moslem, you cannot accept to choose a non-Moslem to be your leader, so it is not the leaders who are cooperating but it is a difference in religion. So if you want to be a good country, to join hands, we have to follow one faith.

What he said in modern period is based on orthodox tradition which has refused to know yet we know from experience that only change is constant. And again, from logic and philosophy that authority is not a formidable and very reliable base of knowledge. For Nzeribe (1988), the utterances of Gumi is the view of Muslim hierarchy in the North. You can see that there is chronic opposition to the good, beauty and the truth if one persists to abide by the orthodox Muslim tradition and these are objects of philosophy. There is equally great opposition to love as no other view is acceptable save that based on "blind" faith, I think it amounts to epistemological suicide, It is the struggle for influence and control between Christianity and Islam that springs up conflicts and crises in society. Kukah commented:

... These two religions are straddled across the Nigerian polity, each no longer knocking and pleading to be 
admitted but seeking to take over the architectural and construction of the Nigerian polity (Kukah, 1994).

Generally we tend to hold and accept that all power belongs to God; this links both politics and religion. For Udoidem:

What is even more intriguing and perplexing is that it is the same concrete human person who assumes both political and religious identity and one necessarily affects the others.

He adds:

What emerges from this ineluctable relationship is that the issue of separation of religion and politics is pragmatically problematic (Udoidem, 1997).

In Igbo language we say mberedenyiri dike, ma mberedekaejjiama dike.

Though problematic to separate these concepts, it is not impossible to have proper delineation of the proposed boundary in order to have a peaceful society devoid of violence and destruction. In order to have society that is peaceful where things will move on well, there is then every need that philosophy will tutor not only politics and religion but equally society as well. There is need to inject not only formal education in the socio-political and philosophic knowledge and wisdom if we should know sound politics and religion. Plato asserts:

Hence I was forced to say in praise of the correct philosophy that it affords a vantage point from which we can discern in all cases what is first for communities and for individuals, and that accordingly the human race will not see better days until either the stock of those who rightly and genuinely follow philosophy acquire political authority, or else the class who have political control be led to some dispensation of providence to be become real philosophers (Plato, 1961).

To be a philosopher is not to have studied philosophy and/or having a degree in philosophy. It is rather having the ability to philosophize. And philosophizing, no doubt, has to do with one's ability to articulate logically, which is anchored on rationality. Aristotle (1984) recognized corporal powers or principles such as nutrition, perception locomotion, etc and still stressed on rationality as a distinctively human characteristic. In his thought, he pointed out two conceptual schemes the speculative and practical thought, the first has the character of (an) end while the latter has the character of or calculates means to an end. Although the attributed rationality to man as a feature or activity of the soul, Freud did point out that there is a mass of irrationality manifested by human beings. Freudian postulation has not and cannot vitiate human rationality rather it aids us to be on our toe knowing that there could be devastating and degenerating tendencies.

Man in the bid of struggling and making adjustments in order to live happily and peacefully has the task of seeking balance between his biological and social natures through the agency of rationality which equally too is a task to be done and nurtured as it confers on man the power to discern, explore and choose when, how and where to put into use his qualities, powers or potentials.

With the aid of rationality man engages in human conduct, which is the sphere of ethics (morality). It is common place to state that every human action is aimed at some specific end or goal or good. Aristotle stated, every art and every inquiry, and similarly every action and choice is thought to aim at some good; and for this reason the good has rightly been declared to be that at which all things aim.

As we have numerous activities, in the same vein, we have numerous ends and goods; hence some would then automatically serve as means to other or further ends. For Aristotle the supreme end is "Eudaimonia" rendered as happiness in English; but should be seen as being related more to "flourishing" or "well-being" than happiness. To flourish to do certain things excellently, and he distinguished between excellence of intellect and character. Njoku comments:

Under excellence of intellect are classified such things as knowledge, good judgement and practical wisdom. Excellence of character includes the moral virtues of courage, generosity, fair mindedness and dispositions such as self-respect and cleverness (Njoku, 2002).

In Aristotle's understanding intellectual excellence marks man out in the family of animals. As such one's well being should have to aligned there to. Is it rationality that informs us that society is not an aggregation, but an association of persons based upon need for survival and well being and upon the capacity of the individual to complete self or realize same. For Messner, it is "an association of men for mutual help in the attainment of the 
full humanity implied in the existential ends" (Messner, 1965).

In society, there is no doubt that social cooperation brings something new and equally aids in enlarging each individual and enrichment of all as all participate in the fulfillment of their purposes in life. Society is ontologically essential for individual existence and his integral human existence, hence rooted in more vital existential ends than other kinds of association which could be referred to as "society". Rationality informs us that at the root of society lie both on the fact of equality of men essentially as each has same spiritual and moral nature points to having some existential ends; be you Christian, Muslim or traditional religionist or even an acclaimed atheist. And the fact of inequality is with regard to man's bodily and sensory natures. It stands to reason then thatone should attain integral human existing by pursuing values and culture which his spiritual and bodily nature demand. Because the spirit is subject to the limitation of matter, man must necessarily strive and struggle for completion; for none alone can attain completion without the cooperation of others as ultimate fulfillment of one's existential ends demand social interaction. Aristotle (1946) recognized this in his Politics and emphasized one who does not need completion (one unable to live in society) must either be a beast or a god.

Experience coupled with human reason has made it clear to us that nature makes nothing in vain. Aristotle (1946) added "for every instrument will be made best if it serves not many purpose but one". It is in the formation of society that nature and end coincide and not in the family established to supply our everyday wants. Njoku commented: The end for which something stands follows a certain order or pattern, and that purpose inversely dictates the order:

For him, citing Aristotle society came

About as a means of securing life itself, it continues in being to secure the good life, it truly exists with the great aim and end as the perfection of its members, living together for mutual complementation (Njoku, 2002).

The emphasis of Aristotle on intellectual excellences, and other philosophers and social thinkers on the relevance of convention in forming of society simply X-rays the indisputable conviction that man is a candidate for interpersonal relation; and cultured life and not civilized per se' as Njoku (2002) thought; as culture has to do with qualities of the mind while civilization seems ephemeral, does not always concern basics. Man is primarily a creature of culture and only graduates into a creator of culture, hence could be said to be born primarily for society as such is a "being-with-others". Who becomes rational and free in the process of interacting with other beings (Dasein) in the understanding of Heidegger (1962). Man is not only a "being-with-others", he is equally a "being-for-others", for he is a stark link between the past and the future. He dialogues with the past and the present, hence his world is never completed. For Njoku

... We realize that history or culture or society is given to humans as unfinished task which is principally handed down as ideas, bundles of possibilities or gateways of inspiration and spring boards of creativity (Njoku, 2002).

So if our duty as men whether we are traditionalists, Christians or Muslims to keep the historical flag of existence flying, likewise the flag of our dear nation flying so as to allow it fly. Alongside those of other nations of the world. How do we do this? We can only succeed in doing it by aligning with the truth. How do we align with the truth? By making efforts to discover the truth and not being not only myopic which we consider as not only epistemological suicide but dogmatic, rigid and unwholesome. Life and society are dynamic, only change is constant.

A critical view and analysis of what we have said so far point towards having dialogic communication with the other in order to hear him, see his viewpoint, think and reflect on it and see whose viewpoint has stronger logic if there could be no synthesis of the views which would aid human flourishing. We need to do this because man is a rational and thinking animal. Certainly Mournier understood the relevance for reaching out to the other when he said "we must find way out of our inwardness". Edward asserts: Man's chief task, is not to master nature but, increasingly to bring about communication leading to universal understanding (Edward, 1968).

Why? Because for Friedman:

In communication, I am revealed to myself together with the other, for in becoming manifest, I am losing myself (as empirical existence) in order to find myself (as potential existenz) (Friedman, 1964).

Do you now see why Islam's view of non-Moslems whereby it offers them no ground for interaction need be 
revisited in order to augur well with the principle of existence? Communication touches the deepest root of our beings, moreso, when it is genuine for it allows us entrance into the world and being of the other, for there is no art to read the mind on the face or from the face. This is why Jaspers poignantly states: An avoidance of true communication is tantamount to a relinquishment of any self-being, if I withdraw from it, I am betraying not only the other but also myself (Jaspers, 1970).

Little surprising Mounier unquestionably asserts:

Common opinion notwithstanding, the fundamental nature of the person is not originality nor self-knowledge nor individual affirmation. It lies not in separation but in communication (Mounier, 1949).

Speech is what we have in common with our kind so nature never made the faculty of concept formation for fun. For Plattel the home of man especially the contemporary man:

Does not lie primarily in a localized milieu but in his fellow-man, man become a person only when he feels that his fellow-man affirms him as such ... indicated as his co-existence. He is a human being among fellow human beings (Plattel, 1965).

Does the stand of Islam encourage this kind of arrangement? By seeing and treating some people as "infidels" and giving them sub-human status Islam fights human existence and moreso human flourishing. Likewise some Christian sects by undue emphasis and stress on "brethren", born againism' while their hearts are still far from God and evident segregation, equally refuse to affirm man hence should be critically assessed for a new mode of relation to spring up or manifest. Man can do all these because he is gifted with rationality and ready to practice openness which is one of the primary movement of any rational creature (in pursuit of the truth). The relevance of rationality should be taken for granted as Descartes popularly known for his "cognito ergo sum"-I think therefore I am, though "non sequitor"-it does not necessarily follow, engaged in methodological skepticism in order to get at a foundation on which to build his philosophic thought. By pointing unto thinking and makingman (substance) divisible into thinking thing and extended thing, he underscores thinking as the principle of unity which centrally should bring about or engineer symbiotic relationship among men moreso in our society with different and hostile worldviews. Experience has taught us that usually growth manifests as a result of a resolved tension. Although it does look like that we have contradictory pairs of opposites in Nigeria, rationality (reason) could be used if applied or employed to resolve these, for Hegel has although made us realize that it is by resolving conflicts of opposites that humanity progresses in his postulation of thesis, anti-thesis and synthesis. Marx equally showed same in his postulation of an emergence of socialism from the conflict between the bourgeoisie and the proletariat.

Because man is gifted with rationality and because he has the ability to change, we "hic et nunc" posit that philosophy departments be established in the universities in the northern part of Nigeria, and again that there be put in place philosophical training starting from our secondary schools so as to arm our children and youths with the tools for proper analysis of statements so as to avoid being bewitched by the use of language. Moreso, to arm them with the canons for rational and logical discourse, in order to produce and have an "army" of people who could recognize the difference between ignorance and wisdom, opinion from fact, opinion from truth, opinion from knowledge among others.

Since philosophy is rendered etymologically as love of wisdom, there is need for proper search for the good, the beauty and the truth for the scriptures says the truth shall set you free. Once the truth is discovered, wisdom is discovered for Jesus said I am the way, the truth and the life. It is wisdom that would aid us know that our religious sentiment need not be given free and unpunctuated expression because the other has his for "virtuo in medio stat" - virtue stands in the middle. Ask yourself why God has not killed all of us in spite of our atrocities? He uses wisdom which he himself is; knowledge has a way of liberating us from shackles of ignorance, myopism, superstition, prejudice, bias of all sorts and fanaticism. Fanaticism, yes, though we need an iota of it to survive in life and succeed. Intellectual enlightenment no doubt could go a long way to assist us in our journey to establishing a peaceful society irrespective of pluralism at various levels. Pluralism for Ekwunifie.

Involves awareness on the part of the affected, of the existential differences in cultural behaviour, philosophy of life and even certain attitudes and values (Ekwunife, 1992).

In order to maintain our pluralistic structure we advocate one more that there is need for strong and whole reaffirmation of the secularity of the Nigerian state. We are not thinking of secularism which is anti-religion, ra- 
ther we suggest government's neutrality in matters of religion, that is where government has no religion of its own and where it does not discrimination on the grounds of religion. Aguwaargued: Modern culture is essentially humanistic and it succeeds to maintain this value by rejecting the tradition of blending religion with other social institutions (Aguwa, 1993).

\section{Conclusion}

Our problems are multi-quam plural, ranging from cosmological exclusivism, lack of leadership, ignorance, corruption and so on. We know that man is both a political and religious animal; hence, we do not advocate a total separation of religion from politics, but we should guard against politicization of religion in order to avoid emotional outburst from such which has escalated our problems by the ensued violence and destruction which claims lives and properties. We should not give irrational latitude to either religion in politics or vice versa, and we would rather we vote for secularity of the Nigerian state. Ronald Flowers asserts: ... A secular state establishes neither atheism nor religion as its official creed. On the contrary, the constitution mandates that the government should remain secular, rather than affiliating itself with religious beliefs or institutions, precisely in order to avoid discriminating among citizens on the basis of the religious beliefs.

The truth is that it is pragmatically difficult, if it is not impossible to separate religion from politics. It is separable conceptually in the world of ideas; hence, caution is called for in the practice of those in our society to avoid violence and "bad" blood. We can harmonize with both the use of our reason and being ever ready to tolerate the other, as tolerance must be ready at hand due to our being a pluralist society. You need to remember that you are not alone; you are a "being-with-others" cooperator.

\section{References}

Achebe, C. (1986). The World of the Ogbanje (p. 10). Enugu: Fourth Dimension Publishers.

Aguwa, J. C. U. (1993). Religious Dichotomy in Nigerian Politics (pp. 4, 9, 16). Enugu: Fourth Dimension Publishers.

Akpunonu, P. D. (1988). Religion and Politics in the Old Testament and in the Intertestamental Era (p. 3). Paper Presented at the 3rd National Conference of Catholic Theological Association of Nigeria (CATHAN) Jos.

Amucheazi, E. C. (1986). Church and Politics in Eastern Nigeria 1945-1966 (p. 5). Lagos: Macmillan.

Aristotle (1975). Nicomachean Ethics Bk 1, Ch1, 1994 a 1-3.

Aristotle (1984). The Complete Works of Aristotle Vol. I Rev Jonathan Barnes (ed) (p. 25). Princeton: Princeton University Press.

Durrant, W. (1920). The Story of Philosophy. New York: Simon and Schuster.

Edward, P. (Ed.) (1968). The Encyclopedia of Philosophy (p. 411). New York: Macmillian Publishing Co.

Ejizu, C. (1986). Continuity and Discontinuty of Igbo Traditional Religion. In E. I. Metuh (Ed.), The Gods in Retreat (p. 143). Enugu: Fourth Dimension Publishers.

Ejizu, C. (1988). Ethics of Politics in Nigeria: The Christian Perspective. Catholic Theological Association of Nigeria, Owerri. The Nigerian Journal of Theology, 28.

Ekwunife, A. N. O. (1992). Politics and Religious Intolerance: The Nigerian Experience (pp. 5, 9, 11, 17). Enugu: Snaap Press Ltd.

Flannery, A. (Ed.) (1975). Vatican Council II: The Conciliar and Postconciliar Documents. In Ekwunife (1992), 981.

Friedman, M. (1964). The Worlds of Existentialism (p. 204). New York: Random House.

Glenn, M. V. (1962). Social of Religion (p. 251). New York: McGraw-Hill Company.

Heidegger, M. (1962). Being and Time. Trans. by John Macquarrire \& Edward Robinson, Oxford: Blackwell.

Iroegbu, P. (2003). Spirituality and Metaphysics (p. 7). Owerri: Enwisdomization Eustel Pub.

Jaspers, K. (1970). Philosophy (Vol. 2, p. 54). Chicago, IL: University of Chicago Press.

Kraft, G. (1979). Christianity in Culture (p. 53). New York: Orbis Books.

Kukah, M. H. (1994). Religion, Politics and Power in Northern Nigeria (p. 9). Ibadan: Spectrum Books.

Kushner, H. (1990). Who Needs God (pp. 59-60). London: Simon \& Schuster Ltd.

Lateef, A. (1974). The Islamic Way of Nation Building in Orita. Ibadan Journal of Religious Studies, 8, $106,107$.

Leon Dare (1985). Politics since Independence. In R. Olaniyan (Ed.), Nigerian History and Culture (p. 189). Ikeji: Longman. Madu, J. (2004). Honest to African Cultural Heritage (pp. 83-84, 95-96). Onitsha: Coskan Associates. 
Madubuko, L. (1994). Igbo Worldview. Enugu, Bigard Theological Studies.

Makozi, A. O. (1988). Religion and Politics in Independent Nigeria: A Historical Analysis. CATHAN, Owerri, The Nigerian Journal of Theology, 3, 4.

Messner, J. (1965). Social Ethics: Natural Law in the Western World (Rev. ed, p. 99). London: B. Herder Book Co.

Metuh, E. I. (1987). Comparative Studies of African Traditional Religions. Onitsha: Imico Publishers.

Mounier, I. (1949). Le Personnalisme (p. 17). Paris: Publisher.

Njoku, F. O. C. (2002). Philosophy in Politics, Law and Democracy (pp. 22, 25, 35, 32). Nigeria: Claretian Institute of Philosophy and Claretian Communications.

Nwala, T. U. (1985). Igbo Philosophy (p. 24). Lagos: Latern Books.

Ogugua, P. I. (2005). Understanding Deities in Igbo-African World: A Religio Philosophical Perspective. In M. Dukor (Ed.), Essence Interdisciplinary - International Journal of Philosophy (No. 2, pp. 64). Nigeria: Essence Library.

Okafor, F. U. (1992). Igbo Philosophy of Law (p. 3). Enugu: Fourth Dimension Pub. Co.

Onuoha, E. (1987). Four Contrasting World-Views. Enugu: Empress Publishers Co. Ltd.

Onyewuenyi, I. (1983). Citing Alpern in "A Philosophical Reappraisal of African Belief in Reincarnation". International Philosophical Quarterly, 22, 163.

Pfeffer, L. (1987). Church, State and Freedom. Boston, MA: Beacon Press.

Plato (1961). The Collected Dialogues of Plato: Including the Letters. Edith Hamilton and Huntington Cairns (Eds.), Princeton, NJ: Princeton University Press.

Plattel, M. G. (1965). Social Philosophy (Duguesne Studies). Louvain: Duguesne University Press, 2.

Russell, B. (1971). Power (pp. 9, 25). London: Unwin Books.

Shagari, S. U. (1983). Speech in NOM: Building a Just Society Together. Lagos: Federal Ministry of Information and Culture.

Skutch, A. (1970). The Golden Core of Religion (pp. 9, 11). London: George Allen and Unwin.

Udoidem, S. I. (1997). Religion in the Political life of Nigeria: A Survey of Religious-Related Crises since Independence. In F. U. Okafor (Ed.), New Strategies for Curbing Ethnic Religious Conflicts in Nigeria (p. 154). Enugu: Fourth Dimension.

Wambutda, D. N. (1986). The Interplay between Cosmology and Theology: A Matrix for African Theologizing. In A. Oduyoye (Ed.), The State of Christian Theology in Nigeria 1980:1981 (p. 41). Ibadan: Day Star Press.

Weber, M. (1964). The Sociology of Religion. Boston, MA: Beacon Press. 